\title{
The Dimensions of Public Policy in Private International Law
}

\author{
Alex Mills* \\ Accepted version: Published in (2008) 4 Journal of Private International Law 201
}

\section{The problem of public policy in private international law}

National courts always retain the power to refuse to apply a foreign law or recognise or enforce a foreign judgment on the grounds of inconsistency with public policy. The law which would ordinarily be applicable under choice of law rules may, for example, be denied application where it is "manifestly incompatible with the public policy ('ordre public') of the forum", , and a foreign judgment may be refused recognition on the grounds that, for example, "such recognition is manifestly contrary to public policy in the [state] in which recognition is sought" 2 . The existence of such a discretion is recognised in common law rules, embodied in statutory codifications of private international law $^{3}$, including those operating between European states otherwise bound by principles of mutual trust, and is a standard feature of international conventions on private international law ${ }^{4}$. It has even been suggested that it is a general principle of law which can thus be implied in private international law treaties which are silent on the issue ${ }^{5}$.

The public policy exception is not only ubiquitous ${ }^{6}$, but also a fundamentally important element of modern private international law. As a 'safety net' to choice of law rules and rules governing the recognition and enforcement of foreign judgments, it is a doctrine which crucially defines the outer limits of the 'tolerance of difference' implicit in those rules ${ }^{7}$. This is a function which it has long performed ${ }^{8}$, and which is increasingly important in multicultural societies and a globalising world. In addition

\footnotetext{
* Slaughter and May Lecturer in Law, Selwyn College, University of Cambridge (alexmills@ cantab.net). Thank you to the anonymous referees and to Kimberley Trapp for their helpful comments. An early version of this paper was presented at the Journal of Private International Law Conference in Birmingham, June 2007.

${ }^{1}$ Convention on the law applicable to contractual obligations, opened for signature in Rome on 19 June 1980, Consolidated at OJ C 027, 26.1.1998 (henceforth, "Rome Convention (1980)"), Art.16.

${ }^{2}$ Council Regulation (EC) No 44/2001 of 22 December 2000 on Jurisdiction and the Recognition and Enforcement of Judgements in Civil and Commercial Matters, OJ L 12, 16.1.2001 (henceforth, "Brussels Regulation (2001)"), Art.34(1).

${ }^{3}$ See, eg, Private International Law (Miscellaneous Provisions) Act 1995, s.14(3)(a)(i).

${ }^{4}$ See, eg, Mosconi, F, "Exceptions to the Operation of Choice of Law Rules" (1989-V) 217 Recueil des Cours 9 at p.44ff.

${ }^{5}$ See Application of the Convention of 1902 Governing the Guardianship of Infants (Netherlands $v$ Sweden) [1958] ICJ Reports 55, particularly the Separate Opinions of Judges Badawi, Lauterpacht, and Quintana and the Declaration of Judge Spiropoulos. Judge Lauterpacht held (at p.92) that "ordre public must be regarded as a general principle of law". But see Lipstein, K, "The Hague Conventions on Private International Law, Public Law and Public Policy" (1959) 8 International and Comparative Law Quarterly 506.

${ }^{6}$ This is not to imply that it is homogenous - see further section 2.2 below.

${ }^{7}$ Note the resolution of the Institute of International Law on "Cultural differences and ordre public in family private international law" (2005) (http://www.idi-iil.org/idiE/resolutionsE/2005_kra_02_en.pdf).

${ }^{8}$ See further, eg, Mills, A, "The Private History of International Law" (2006) 55 International and Comparative Law Quarterly 1 at pp.13, 36, 40.
} 
to this traditional role, recent cases suggest an expansion in the use of public policy derived from sources external to the state, such as European and international law, a development which quietly suggests a revolutionary change in its character and effects.

However, public policy exceptions in private international law have also been frequently criticised for their uncertainty ${ }^{9}$. This is particularly true in the common law world, and the focus of analysis in this article will be on the position of public policy under English law ${ }^{10}$. The criticisms break down into two distinct but related concerns. First, the exercise of public policy is often characterised and maligned as involving a broad and unfettered discretion, giving excessive and unguided power to the judiciary. Second, critics point out that when the courts do decide to apply public policy it is not always easy to identify in advance what the content of public policy actually is or what the consequences of its application will be. The objections raised here are to the unpredictability of the rule, which, aside from raising concerns about rationality and legitimacy, risks undermining the concern of private international law, particularly in the common law world, with meeting party expectations.

The courts in practice acknowledge that there must be limits on the application of public policy in private international law, accepting the need for a cautious approach, avoiding "national exclusiveness and prejudice impatient of the application of foreign law" . English courts have noted that "the court will be even slower to invoke public policy in the field of conflict of laws than when a purely municipal legal issue is involved"12, and have accepted the need for "commonsense, good manners, and a reasonable tolerance" "13, "the greatest circumspection"14, and "judicial restraint"15, noting that "the law proceeds charily where grounds of public policy are invoked"16. They have not, however, provided guidelines on how to formulate the limits on the application of public policy in private international law, lamenting its "imprecision, even vagueness"17 but accepting that the "public policy principle eludes more precise definition" 18 . This does not merely mean that the decisions of the courts are unpredictable, but also that it is very difficult to find satisfactory reasons to criticise any application of public policy.

\footnotetext{
${ }^{9}$ Possible exceptions may be admitted for principles deriving from public policy which have crystallised into distinct rules of private international law (such as the defences of fraud and natural justice which operate against the recognition or enforcement of a foreign judgment), or have been adopted in statute as mandatory rules of the forum, thus overriding the ordinary application of foreign law. These are not considered in this article.

${ }^{10}$ The relative underdevelopment of English rules of public policy is often attributed to the dominance of the lex fori in English law in matters dealing with family law or personal status, where many civil law systems would apply the law of common nationality of the parties, giving a greater role to public policy exceptions: but see Enonchong, N, "Public Policy in the Conflict of Laws: A Chinese Wall Around Little England?" (1996) 45 International and Comparative Law Quarterly 633 at p.637ff.

${ }^{11}$ Application of the Convention of 1902 Governing the Guardianship of Infants (Netherlands $v$ Sweden) [1958] ICJ Reports 55 at 94 (Separate Opinion of Judge Lauterpacht).

${ }^{12}$ Vervaeke $v$ Smith [1983] 1 AC 145 at 164.

${ }^{13}$ Cheni $v$ Cheni [1965] P 85 at 99; see also KC \& Anor v City of Westminster Social \& Community Services Dept \& Anor [2008] EWCA Civ 198.

${ }^{14}$ Kuwait Airways Corporation v Iraqi Airways Co \& Anor [2002] UKHL 19 at [18], per Lord Nichols.

${ }^{15}$ Kuwait Airways Corporation v Iraqi Airways Co \& Anor [2002] UKHL 19 at [140], per Lord Hope.

${ }^{16}$ Cheni v Cheni [1965] P 85 at 97.

${ }^{17}$ Kuwait Airways Corporation v Iraqi Airways Co \& Anor [2002] UKHL 19 at [18], per Lord Nichols.

${ }^{18}$ Kuwait Airways Corporation v Iraqi Airways Co \& Anor [2002] UKHL 19 at [17], per Lord Nichols.
} 
These concerns with uncertainty may be collectively summarised in the famous aphorism that public policy "is a very unruly horse and when once you get astride it you never know where it will carry you" ${ }^{\text {" }}$. Lord Denning responded with his own characteristically lyrical assertion, that:

"With a good man in the saddle, the unruly horse can be kept in control. It can jump over obstacles. It can leap the fences put up by fictions and come down on the side of justice" 20 .

This article addresses the question of why and how public policy is or ought to be 'reined in'. It begins by addressing the theoretical question of why there should be limits on public policy, recognising the importance of constitutional concerns. Taking the view that the use of public policy must be restricted, it then develops three distinct principles or guidelines to explain and constrain the way in which public policy is, and ought to be, applied by the courts. These guidelines may be understood as constraints upon public policy operating in different 'dimensions'. Using these constraints as parameters, it is possible to produce a 'map' of the principled application of public policy in private international law. Analysis of English case law reveals that, despite the lack of guidelines articulated by the courts, in practice the application of public policy largely corresponds to this principled map. The analysis in this article thus does not propose radical changes in the application of public policy in private international law, but rather attempts to explicate the unarticulated principles behind the practice of the courts. In doing so, it suggests ways in which the explanation and justification for the application of public policy might be improved, in the hope of influencing judicial practice and allaying the criticisms of uncertainty attached to this important doctrine.

\section{Why should there be limits on public policy in private international law?}

A preliminary question is to ask whether, and if so why, there should be limits on public policy in private international law at all, or whether it might properly be viewed as 'discretionary' in character. On this question it is necessary first and foremost to avoid confusion between two types of discretion - discretion for the state and discretion for the judge ${ }^{21}$.

\footnotetext{
${ }^{19}$ Richardson v Mellish [1824] 2 Bing 229 at 252.

${ }^{20}$ Enderby Town Football Club Ltd v The Football Association Ltd [1971] 1 All ER 215 at 219.

${ }^{21}$ An issue famously considered by Cardozo J in Loucks $v$ Standard Oil Co of New York (1918) 224 NY 99 at 110:

"The sovereign in its discretion may refuse its aid to the foreign right .... From this it has been an easy step to the conclusion that a like freedom of choice has been confided to the courts. But that, of course, is a false view. The courts are not free to refuse to enforce a foreign right at the pleasure of the judges, to suit the individual notion of expediency or fairness. They do not close their doors unless help would violate some fundamental principle of justice, some prevalent conception of good morals, some deep-rooted tradition of the common weal."
} 


\subsection{Distinguishing state and judicial discretion}

It is generally considered that private international law rules are discretionary for each state, that (in the absence of a binding treaty) public international law imposes no significant restrictions on private international $\mathrm{law}^{22}$. Such a perspective, connected to the 'local law' theory of private international law ${ }^{23}$, proceeds from the observation that "private international law is really a branch of municipal law" 24 . From this perspective, choice of law rules and rules governing the recognition and enforcement of foreign judgments are discretionary for the local legal system - optional, serving domestic policy objectives, and subject only to internal political constraints ${ }^{25}$.

Even if private international law possesses a discretionary character at the international level, this is, however, a strictly separate question from whether rules of private international law themselves permit judicial discretion. A state could adopt rules of private international law which limit judicial discretion in support of a variety of domestic policies, including national conceptions of justice and fairness, and perhaps most obviously the desire to give private parties a more certain and predictable legal order ${ }^{26}$.

Where such rules are adopted, for whatever reason, the presence of an apparently discretionary public policy exception must not be confused with the adoption of a discretionary rule. The risk here, by no means unique to this context or even to private international law, is that the exception could swallow the rule. To use the words of one United States court:

"Since every law is an expression of the public policy of the state, some higher threshold is needed to prevent the forum's law from being applied in every case. A strict construction of the public policy exception [is] necessary to prevent the whole field of conflicts of law from collapsing in on itself"27.

An excessive application of a public policy discretion could risk undermining the very existence of rules of private international law. If the rules requiring application of a foreign law or the recognition and enforcement of foreign judgements were too

\footnotetext{
${ }^{22}$ But note the suggestion that "a Judge should, of course, be very slow to refuse to give effect to the legislation of a foreign state in any sphere in which, according to the accepted principles of international law, the foreign state has jurisdiction": Empresa Exportadora de Azucar v Industria Azucarera Nacional SA (The Playa Larga and The Marble Islands) [1983] 2 Lloyd's Rep 171 at 190. The relationship between public and private international law is explored in more detail in a forthcoming book by the author, to be published by Cambridge University Press, entitled "The Confluence of Public and Private International Law".

${ }^{23}$ See, eg, Cook, WW, "The logical and legal bases of the conflict of laws" (1924) 33 Yale Law Journal 457.

${ }^{24}$ Dynamit v Rio Tinto [1918] AC 260 at 302.

${ }^{25}$ A position close to this is adopted by Briggs, A, "Foreign Judgments and Human Rights" (2005) 121 Law Quarterly Review 185, who argues in the context of the recognition and enforcement of foreign judgments that the act of recognition is an internal act with only domestic effects.

${ }^{26}$ Equally, even if international law imposed limits on private international law, it might (depending on the nature of those limits) be possible to have a purely discretionary system of rules of private international law, and, through wise judicial fiat, be perfectly compliant.

${ }^{27}$ Tucker $v$ RA Hanson Co (1992) 956 F 2d 215 at 218.
} 
frequently set aside, this would no doubt lead to the accusation that public policy, and not private international law, dictated the applicable law $^{28}$.

\subsection{Constitutional issues}

It might, however, be argued that public policy is a mechanism to ensure 'justice' between the parties - a mechanism which must be essentially unrestrained if it is to allow a judge to achieve that objective ${ }^{29}$. Although of course judges are invited to apply the public policy of the state, not their own policies, this approach risks empowering judges who are not servants to higher legal principles, but autocrats of their courtrooms, applying a public policy which is a product of "the idiosyncratic inferences of a few judicial minds" 30 .

It has long been pointed out that excesses of judicial discretion may be inconsistent with the English constitutional conception of the rule of law $^{31}$. The constitutional dimension to this analysis is clearest where choice of law rules or rules governing the recognition and enforcement of foreign judgments are expressed in a statute. In this situation, the English parliament has set a policy of recognising or enforcing foreign laws or judgments. The courts must have limits on their application of public policy if these are not to undermine the rules which parliament has established. This is particularly the case given that parliament may itself override rules of private international law through statutory mandatory rules, and the judicial application of public policy only arises where it has not done so $^{32}$. It must be acknowledged that the scope of the exception may vary between different rules and in different contexts - for example, public policy may mean different things as part of the rules on the recognition and enforcement of foreign judgements when operating as part of the common law or between Member States of the European Union as part of the Brussels Regulation ${ }^{33}$. While it may be difficult to determine exactly how broad public policy is intended to be, it must nevertheless be presumed in each context that parliament cannot have intended to establish an exception whose effect is to undermine entirely the application of the rule. These concerns equally apply where the rules are sourced from European regulations which have direct domestic effect.

Even where choice of law or judgment recognition rules are purely common law, developed by English courts themselves, there is a constitutional imperative for giving effect to them. To apply a public policy discretion in an excessive way would be to undermine the binding authority of the earlier decisions which developed the rule in

\footnotetext{
${ }^{28}$ Some critics of traditional approaches to private international law in the United States in the early twentieth century did suggest that 'escape devices' like public policy were more significant than ostensibly fixed rules: see, eg, Lorentzen, EG, "Territoriality, Public Policy and the Conflict of Laws" (1924) 33 Yale Law Journal 736 at p.746ff.

${ }^{29}$ There is some support for such a perspective in United States approaches. Its influence in English case law is critically discussed in Collins, L (ed), "Dicey, Morris and Collins on the Conflict of Laws" (14 ${ }^{\text {th }}$ edn, 2006) at p.98; see also Nygh, PE, "Foreign Status, Public Policy and Discretion" (1964) 13 International and Comparative Law Quarterly 39 at p.48ff.

${ }^{30}$ Fender $v$ St John-Mildmay (1938) AC 1 at 12 (discussing domestic public policy).

${ }^{31}$ See, eg, Dicey, AV, "Introduction to the Study of the Law of the Constitution" ( $8^{\text {th }}$ edn, 1915). Nygh argued that "The courts might just as well abandon any attempt to formulate and apply defined rules of law, if these can be overridden by an undefinable discretion": Nygh, PE, "Foreign Status, Public Policy and Discretion" (1964) 13 International and Comparative Law Quarterly 39 at p.51.

${ }^{32}$ Nutting, CB, "Suggested Limitations on the Public Policy Doctrine" (1935) 19 Minnesota Law Review 196.

${ }^{33}$ See further section 3.3 below.
} 
question. It would effectively permit the court to evade the doctrine of precedent, relying on an expansive view of the exceptions to the prior established rule to undermine the binding effect of the rule itself ${ }^{34}$.

In essence, this approach notes that choice of law rules and rules governing the recognition and enforcement of judgments are themselves public policies. Rules of private international law which dictate the application of foreign law or the recognition or enforcement of a foreign judgment give effect to policy decisions. Whatever public policy is being invoked through a discretionary exception must be weighed against the public policy inherent in the rule, and the constitutional authority behind the adoption of that policy by parliament or by the courts themselves ${ }^{35}$. Courts cannot be entirely free to give effect to discretionary public policy without undermining other public policies and values.

\section{What limits should apply to public policy in private international law?}

The starting point for developing principled limits for the application of public policy in private international law is an understanding of the exact function and effect of public policy in this context. Public policy may be seen as a type of exceptional choice of law rule - a recognition which suggests a number of constraints which should operate to limit its application.

\subsection{Public policy as a choice of law rule}

The ordinary application of a choice of law rule is to select a governing law for a private dispute. If a dispute is brought before an English court, and English law is designated by the applicable English choice of law rules, then (with the possible exception of the rules concerning contracts whose performance is or becomes unlawful according to the place of performance ${ }^{36}$ ) no issue of public policy arises ${ }^{37}$.

\footnotetext{
${ }^{34}$ Public policy itself is frequently viewed as not subject to the doctrine of precedent, because of its need to dynamically reflect changes in social values.

${ }^{35}$ The idea that public policy ought to defer to the principles underlying private international law also supports the (somewhat controversial) proposition that public policy may not be available in defence of the enforcement of a foreign judgment if it could have been raised before the foreign court but was not: see, eg, Israel Discount Bank of New York v Hadjipateras [1983] 3 All ER 129.

${ }^{36}$ See, eg, Foster v Driscoll [1929] 1 KB 470; Regazzoni v KC Sethia Ltd [1958] AC 301. These may be explained as a special application of English public policy in support of a foreign law - an English policy that parties should not be held bound by a contract whose performance is or becomes unlawful according to the place of performance. Alternatively, they may be explained as rules of substantive English law, whereby it is an implied term of a contract governed by English law that its performance must remain lawful according to the law of the place of performance. The case law does not clearly distinguish between these justifications, but the distinction is important - but if the latter is correct, the principle should only apply to a contract governed by English law; if the former is correct, it would apply to prevent enforcement of a contract governed by one foreign law whose performance was unlawful according to another foreign law, the law of its place of performance. Note similarly $R e$ Emery's Investment Trusts [1959] 1 All ER 577, where equity refused to come to the aid of a participant in a scheme to evade foreign tax laws.

${ }^{37}$ Note, in this context, the rejection by the UK of Art.7(1) of the Rome Convention (1980), which would permit English courts to apply foreign public policy; see Dickinson, A, “Third-Country Mandatory Rules in the Law Applicable to Contractural Obligations: So Long, Farewell, Auf Wiedersehen, Adieu?" (2007) 3 Journal of Private International Law 53; Chong, A, "The Public Policy and Mandatory Rules of Third Countries in International Contracts" (2006) 2 Journal of Private
} 
English law must be assumed to be compatible with English public policy. If foreign law is chosen, the effect of public policy is to apply a local norm in priority over that foreign law ${ }^{38}$. The application of English public policy as a basis for refusing to apply a foreign law thus constitutes a rejection of the ordinary application of the choice of law rule, the selection of foreign law, in favour of English norms. The application of public policy is essentially an implicit and overriding choice of English law.

The fact that the foreign law is disapplied on the grounds of an English policy is a distinct point from the debate as to what the appropriate consequences of an application of public policy should be. Having excluded the application of a particular rule of foreign law, it is unclear whether the lacuna should be filled with the residual applicable law or the law of the forum ${ }^{39}$ - a point which distinguishes the (negative) conception of public policy examined in this article from the (positive) conception of public policy expressed through mandatory rules. The answer to this problem must depend on whether such a residual applicable law, compatible with local public policy, can be identified and applied to the dispute. Where this is the case, it ought to be applied to give effect to the policies underlying choice of law rules ${ }^{40}$. Where it is not possible to apply the remainder of the applicable law, the law of the forum is generally considered the most appropriate alternative ${ }^{41}$, although this will be discussed further below ${ }^{42}$. In either case, whatever positive law is introduced in place of the offensive foreign law, the negative exclusionary effect of the application of English public policy remains an application of local norms.

In the context of the recognition and enforcement of foreign judgments, a similar analysis applies. If the foreign court has applied English substantive law, then no issue of public policy will ordinarily arise, except potentially in respect of foreign procedural law, again on the basis that English law must be assumed to be compatible with English public policy. A very serious failure to apply English law correctly might, at least theoretically, give rise to a claim that the foreign proceedings breached standards of natural justice, but even a decision based on an incorrect application of

International Law 27. The recently adopted Regulation of the European Parliament and of the Council on the law applicable to contractual obligations (Rome I) (6 June 2008, 2005/0261 (COD)) contains (in Art.9(3)) a much more heavily qualified provision, which is broadly consistent with the English approach to foreign illegality noted above.

${ }^{38}$ Aside from the cases on foreign illegality noted above, English courts have rejected arguments that public policy can be used to justify the application of foreign law: see, eg, Peer International $v$ Thermidor Publishers [2003] EWCA Civ 1156; Bank voor Handel v Slatford [1951] 2 All ER 779.

${ }^{39}$ See, eg, Blom, J, "Public Policy in Private International Law and Its Evolution in Time" (2003) 50 Netherlands International Law Review 373, pp.375-6; Lagarde, P, "Public Policy", Chapter 11, in Lipstein, K (ed), International Encyclopedia of Comparative Law, Vol III: Private International Law (1994) at [59ff]; Mosconi, F, "Exceptions to the Operation of Choice of Law Rules" (1989-V) 217 Recueil des Cours 9 at p.109ff.

40 Thus, the House of Lords used public policy only to "disregard a provision in the foreign law" in Kuwait Airways Corporation v Iraqi Airways Co \& Anor [2002] UKHL 19 at [18], per Lord Nichols, going on to apply, eg, residual provisions of the Iraqi Civil Code (at [45]-[46].)

${ }^{41}$ The application of English law is sometimes said to follow from the (dubious) presumption that foreign law, if unproven, is the same as English law: see, eg, Briggs, A, "Public Policy in the Conflict of Laws: a Sword and a Shield?" (2002) 6 Singapore Yearbook of International Law 953 at p.971. This presumption may itself be the subject of criticism on grounds similar to those explored in this paper that it provides for the unprincipled application of forum law (eg, without consideration of proximity see section 3.2 below). See further Fentiman, R, "Foreign Law in English Courts" (1998); Shaker v AlBedrawi [2002] EWCA Civ 1452.

${ }^{42}$ See section 3.2 below. 
English law will not be contrary to English public policy ${ }^{43}$. Where, however, a foreign court applies a foreign law (including but not necessarily its own), whether as part of substantive or procedural rules, there is a possibility that the content of the law, or the outcome of its application, could be contrary to English norms. A refusal to recognise or enforce a foreign judgment on the grounds of its incompatibility with English public policy is a refusal to give effect to foreign law - an exception to the usual deference given by the English court to a prior foreign determination of a dispute or issue between the parties. It is, again, an implicit and overriding prioritisation of English norms.

The application of public policy is not just an exceptional choice of law rule because it chooses local law in circumstances which are an exception to the usual choice of law process. It is exceptional also because it is a choice of law rule which is attentive to the substantive content of the applicable law. In the context of choice of law rules, it is the only basis on which an English court will examine the content of foreign law before making the determination of what law to apply ${ }^{44}$. This is true regardless of the position which is taken on the contentious issue of whether public policy is addressed purely to the foreign law, or to its application in the specific case at hand ${ }^{45}$. Both possibilities probably should be accepted - public policy is ordinarily attentive to the specific context of each case, but if a law is (exceptionally) "so grave an infringement of human rights that the courts of this country ought to refuse to recognise it as a law at all"46, then it is difficult to see that it should ever be applied ${ }^{47}$. In either case, it is necessary to examine the substantive content of the foreign law to make the determination. In the context of the recognition and enforcement of foreign judgments, public policy is, again, the only ground on which an English court may examine the substance of the foreign decision.

Viewing public policy in this way, as an exceptional choice of law rule, has two evident consequences. The first is that this exceptional character provides in itself a justification for limiting the application of public policy - it embodies an approach (examining the substance of foreign law) which is, in general, viewed as contrary to English principles of private international law. The second consequence is that, despite this exceptional character, recognising that public policy is a type of choice of law rule suggests that it should be subject to the restraints ordinarily applicable to choice of law rules - the limits of its operation should be governed by the same policies or principles which underpin and constrain choice of law rules themselves.

This analysis is consistent with and draws on the constitutional arguments examined above for limits on public policy in private international law. The application of public policy should be balanced against the public policy of private international law

\footnotetext{
${ }^{43}$ Godard v Gray (1870) LR 6 QB 139.

${ }^{44}$ The possibility of looking at the content of the competing laws is a distinguishing features of a number of approaches to choice of law in the United States, where this examination may be conducted as part of the analysis of competing government interests or directly in determining the 'better law': see, eg, Symeonides, SC, “American Conflicts Law at the Dawn of the 21st Century" (2000) 37 Willamette Law Review 1; Leflar, RA, "Choice-Influencing Considerations in Conflicts Law" (1966) 41 New York University Law Review 267.

${ }^{45}$ See, eg, Lagarde, P, "Public Policy", Chapter 11, in Lipstein, K (ed), International Encyclopedia of Comparative Law, Vol III: Private International Law (1994) at [24ff].

${ }^{46}$ Oppenheimer v Cattermole [1976] AC 249 at 278.

${ }^{47}$ See further discussion in section 6 below.
} 
itself - the public policy embodied in choice of law rules and rules governing the recognition and enforcement of foreign judgments. This concern is met by the recognition that public policy is effectively an exceptional choice of law rule, whose operation must be constrained by the ordering principles which operate behind other choice of law rules. The next stage in the analysis of public policy must then be to identify these principles.

\subsection{Proximity}

Choice of law rules embody a policy determination of which legal system is most 'interested' in a dispute or has the greatest 'proximity' to the dispute, and should therefore have regulatory authority over it. The diversity of choice of law rules around the world reflects the variety of possible interpretations of what constitutes an 'interest' and how different interests are to be balanced against each other.

Some choice of law rules are open textured and allow the courts to make their own determination of proximity, taking into consideration a wide variety of factors. This is frequently the case, for example, in the context of the law applicable to a contract in the absence of choice by the parties ${ }^{48}$. In some United States approaches to choice of law, the courts are invited to conduct a comparative interest analysis, based on an examination of both the objective factors connecting the dispute or the disputants with a particular place, together with competing state policies and statutes ${ }^{49}$. Other choice of law rules determine the greatest interest directly through a fixed rule - for example, the lex situs rule in the context of choice of law in property ${ }^{50}$. In the context of choice of law in contract, the selection of a governing law by the parties is (under both common law $^{51}$ and the Rome Convention ${ }^{52}$ ) given overriding effect as a determination of interest, respecting the party autonomy underlying contract law itself. In an effort to balance the advantages of each approach, and the demands of both predictability and flexibility, many choice of law rules combine fixed rules with open textured rules. This is the case, for example, in the choice of law rule for contracts under the Rome Convention (involving, in the absence of party choice, presumptions subject to a flexible exception ${ }^{53}$ ) and for torts under the Private International Law (Miscellaneous Provisions) Act 1995 and Rome II Regulation (2007) (each of which combines a lex loci delicti rule with a flexible exception $)^{54}$.

The key point is that, regardless of whether a fixed or open textured choice of law rule is adopted, there are a wide variety of interests under consideration in a dispute over the applicable law. This is not to endorse interest analysis as a choice of law rule, but to suggest that any choice of law rule itself implicitly constitutes a form of interest analysis. The mere fact that a fixed rule may determine that a foreign legal system has the greatest proximity to the dispute, or has the greatest interest in it, does not exclude

\footnotetext{
${ }^{48}$ See, eg, Amin Rasheed Shipping Corp v Kuwait Insurance Co [1984] 1 AC 50.

${ }^{49}$ See, eg, Restatement (Second) of the Conflict of Laws, American Law Institute (1969) s.6. This approach arguably subsumes elements of a public policy analysis within the choice of law rule, reducing the importance of public policy in the modern private international law of the United States.

${ }^{50}$ See, eg, Winkworth v Christie, Manson \& Woods [1980] Ch 496.

${ }^{51}$ See, eg, Vita Food Products Inc v Unus Shipping Co Ltd [1939] AC 277.

${ }^{52}$ Rome Convention (1980), Art.3.

${ }^{53}$ Rome Convention (1980), Art.4.

${ }^{54}$ Private International Law (Miscellaneous Provisions) Act 1995, ss.11-12; Regulation (EC) No $864 / 2007$ of the European Parliament and of the Council of 11 July 2007 on the law applicable to noncontractual obligations ("Rome II"), Art.4.
} 
the possibility that the law of the forum may also have an interest. The fact that the balance of interests in an open textured rule may tip in favour of the application of a foreign law does not exclude the existence of other interests pointing towards the law of the forum. Behind the mechanics of specific choice of law rules, the underlying question is one of determining which legal system is most interested in the context of a variety of competing factors - it is a question of degree. This means that even if choice of law rules dictate that foreign law is to be applied to a dispute, there can still be a substantial domestic interest in the dispute. Despite a decision by an English court that foreign law is applicable, a number of factors may still connect the dispute to England. These factors may sometimes be identified in the choice of law rule itself, either as part of an open textured rule ${ }^{55}$ or as 'subsidiary' choice of law rules ${ }^{56}$; in other cases this may require the court to conduct its own evaluation of the connecting factors, perhaps more akin to a US style interest analysis approach. In each case, the strength of those factors can be examined to determine how interested English law is in the dispute, the degree of proximity of the dispute to the forum.

Determining the proximity of the dispute is important, because the invocation of local public policy, itself an application of local law, needs to be justified based on the same criteria which would be used to justify the application of local law to the entirety of the dispute. There must be some sort of connection such that the application of the local policy is appropriate, because the forum state is sufficiently interested in the dispute that it should have (at least partial) regulatory authority over $\mathrm{it}^{57}$. Like any other application of local law, the use of public policy should depend on an examination of the connecting factors operating between the dispute and the forum state $^{58}$. The weaker this interest is, the more that public policy should be restricted. The stronger this interest is, the greater the degree of proximity, the greater the justification for the application of public policy.

It is of course not only the forum which may have an interest in a dispute otherwise governed by foreign law. This incidentally seems to suggest the most principled answer to the problem identified above as to what law to fall back on after an application of public policy ${ }^{59}$. If possible, the court should apply the remainder of the

\footnotetext{
${ }^{55}$ In choice of law in tort, eg, the factors identified in section 12 of the Private International Law (Miscellaneous Provisions) Act 1995.

${ }^{56}$ For example, if the parties have chosen a law to govern their contract, the rules which would determine the applicable law in the absence of such a choice - Article 4 of the Rome Convention might aid determination of the proximity of the dispute with England.

${ }^{57}$ Thus, "the strength of a public policy argument must in each case be directly proportional to the intensity of the link which connects the facts of the case with this country" - Kahn-Freund, O, "Reflections on Public Policy in the English Conflict of Laws" (1954) 39 Transactions of the Grotius Society 39 at p.58; see also Kahn-Freund, O, "General Problems of Private International Law" (1974-III) 143 Recueil des Cours 139 at pp.428-9.

${ }^{58}$ In Application of the Convention of 1902 Governing the Guardianship of Infants (Netherlands v Sweden) [1958] ICJ Reports 55, Judge Lauterpacht expressed the view that international law defines limits on the permissible applicability of public policy, perhaps the need for a "close territorial connection" (at pp.97-8). Judge Quintana expressed the view (at p.108) that "before the ordre public of a country may be validly invoked against an international convention there must exist a substantive connection between the person concerned and the territory". While an international convention could clearly imply additional limits on the exercise of public policy (perhaps increasing the necessary degree of connection), there is no reason why a substantive connection would not also be required outside of this context.

${ }^{59}$ See section 3.1 above; Lagarde, P, "Public Policy", Chapter 11, in Lipstein, K (ed), International Encyclopedia of Comparative Law, Vol III: Private International Law (1994) at [63].
} 
applicable law, without the part which is offensive to public policy. If this is not possible, the usual approach is to turn to English substantive law. But a better approach would be to consider which state has the next greatest interest in governing the dispute. This may be the forum, which will undoubtedly have some interest giving rise to its jurisdiction over the dispute and the application of its public policy ${ }^{60}$. It may equally, however, be another foreign state, whose law should therefore fill the lacuna created by the exclusionary application of public policy. This would not constitute an application of foreign public policy or foreign mandatory rules ${ }^{61}$, but an application of foreign substantive law as the result of a 'subsidiary' choice of law rule. Similarly to the analysis above, in some cases such a rule may be derived from the choice of law rule $^{62}$; in other cases it may require a more ad hoc determination of the interests of affected states.

\subsection{Relativity}

An English court will ordinarily apply foreign law or recognise and enforce a foreign judgment even if the result is different from that which would be reached under English law, and probably even if the cause of action is unknown to English law ${ }^{63}$. A refusal to do so on the grounds of public policy is effectively a statement that the differing outcome of the dispute, or the way in which foreign law is different from local law, is unacceptable in this particular, exceptional case. The application of public policy is therefore really a question of the limits of tolerance. This insight invites the realisation that the question of the application of public policy should also depend on the character of the policy itself which might be applied.

To understand this further it is necessary to recognise that norms possess a range of degrees of 'relativity'. Sometimes a distinction is drawn between three types of public policy: internal public policy, or ordre public interne (applying purely to domestic cases, for example, to invalidate a contract governed by English law), international public policy, or ordre public international (applying in the context of private international law) and 'truly international' public policy, or ordre public veritablement international (public policy which is derived from international law discussed further below ${ }^{64}$. These categories do not, however, indicate clearly distinct types of norms, but merely positions on a continuum. At one end of the spectrum are purely domestic considerations which are matters of local policy and which, it is accepted, could easily be different, for example, the doctrine of consideration in contract law. At the other end are the most elemental values, for example, fundamental human rights norms, which are (and, according to the states who do adopt them, must be) shared by all states as basic elements of public policy. Most norms will be somewhere in between - policies which a state is committed to, which

\footnotetext{
${ }^{60}$ Although, as will be seen in sections 3.3 and 4.3 below, in some cases the application of public policy may be justifiable without any degree of proximity.

${ }^{61}$ See further section 3.1 above.

${ }^{62}$ For example, if the law selected by the parties to govern a contract was contrary to public policy, the court could apply the law determined by the choice of law rule which would apply in the absence of such a choice - Article 4 of the Rome Convention.

${ }^{63}$ See, eg, Cablevision Systems Development Co v Shoupe (1986) 39 WIR 1; Anderson, W,

"Enforcement of Foreign Judgments Founded Upon a Cause of Action Unknown in the Forum" (1993) 42 International and Comparative Law Quarterly 697.

${ }^{64}$ See, eg, Burger, DC, "Transnational Public Policy as a Factor in Choice of Law Analysis" (1984) 5 New York Law School Journal of International and Comparative Law 370 at p.374ff.
} 
are not shared universally, but where the state's commitment entails some degree of lack of tolerance for breach of the norms. Public policy is not invoked just because foreign law is different from local law, but because local law is intolerant of the way in which it is different. The more absolute the conception of a norm is, the less room there is for tolerance of difference, and the more likely it is that public policy will be invoked to give effect to the norm.

The characterisation of a norm as 'absolute' is, in fact, just one way in which the relativity of a norm can be reduced. This occurs in any context in which there is a belief that the policy is both applicable locally and is (or ought to be) applicable in the foreign legal system whose law governs the dispute. There are four distinct ways in which public policy can have diminished relativity in this sense.

First, public policy can be shared in a bilateral sense. If two states happen to share the same public policy, then there is a strong argument that the courts of each state should be prepared to apply this public policy where the law of the other state is in breach of it. This may be the result of a coincidence of policy, or of a derivative recognition of the policy of one state by another. For example, as noted above ${ }^{65}$, under English law, there is a policy against the enforcement of contracts which are or become unlawful according to the law of the place of performance of the contract. One interpretation of this rule is that English courts are in effect adopting the public policy (expressed through its domestic law) of a foreign state. Where public policy is shared with or derived from the foreign law under consideration, there is a stronger argument that the courts should be prepared to apply this form of public policy regardless of the proximity of the dispute with the forum.

Second, public policy can be shared in a regional sense. For example, the European Convention on Human Rights ("ECHR") provides a source of regional norms which are viewed as fundamental and shared between the states who are parties to the Convention. If a dispute involves a number of states who are parties to the ECHR, then the policies it embodies possess an essentially communal character. To the extent that public policy is European in its origin and conception, it is no longer a source of national variation in the application of the rules of private international law, a residual (defensive) expression of national values. Instead, the application of European public policy gives (positive) effect to shared values, ensuring that the application of private international law rules does not breach fundamental rights ${ }^{66}$.

\footnotetext{
${ }^{65}$ See section 3.1 above.

${ }^{66}$ Muir Watt, H, "Evidence of an Emergent European Legal Culture: Public Policy Requirements of Procedural Fairness Under the Brussels and Lugano Conventions" (2001) 36 Texas International Law Journal 539. Recital 32 of the Rome II Regulation (2007) contemplates the use of public policy to refuse to apply foreign laws providing for "exemplary or punitive damages of an excessive nature", but arguably leaves ultimate determination of this issue to each Member State. A more extensive "clarification of the meaning of public policy at Community level" had been proposed by the European Parliament, which would have included a prohibition on such damages as part of the definition of public policy, in addition to "fundamental rights and freedoms as enshrined in the European Convention on Human Rights, national constitutional provisions [and] international humanitarian law" - European Parliament legislative resolution on the proposal for a regulation of the European Parliament and of the Council on the law applicable to non-contractual obligations ("Rome II") (A60211/2005, COM(2003)0427 - C5-0338/2003 - 2003/0168(COD)), Amendment 50.
} 
Third, public policy can be absolute, meaning that it is (at least prescriptively) shared in a universal sense. This is clearest where it derives from agreed international norms, such as those expressed in customary international law or widely adopted international treaties ${ }^{67}$. The most obvious examples of norms which might be recognised in this way are norms of international human rights. This form of public policy is sometimes referred to as 'transnational' public policy, or 'truly international public policy ${ }^{68}$. The application of this form of public policy has had only limited articulation and exploration by common law judges and theorists - it has been cautiously observed that "local values ought not lightly to be elevated into public policy on the transnational level"69. In national law, the special character of this form of public policy is recognised in France and Germany, where a distinction is drawn between public policy derived from domestic norms and public policy which is derived from obligations under international law $^{70}$.

One of the clearest expressions of this idea is found in the context of international arbitration, where its development reflects the need for arbitrators to find a way to recognise public interests (for example, against corruption) in a way which does not compromise the private (non-state) character of the system of arbitration.

International arbitrators have conceptualised a body of both substantive and procedural international public policy, drawing on principles which are (or are perceived to be, or it is thought ought to be) universally adopted in national legal systems ${ }^{71}$. The application of these principles thus accommodates public interests and

\footnotetext{
${ }^{67}$ Mann notes the argument that "all rules of public international law are of necessity so fundamental and essential an element of the legal order that they are part of public order", but prefers the direct application of public international law by domestic courts in this context "without the interposition of public policy", in order "to exclude the discretionary flavour which is inherent in ordre public" : Mann, FA, "Conflict of Laws and Public Law" (1971-I) 132 Recueil des Cours 107 at p.155. See also Vest, LL, "Cross-Border Judgments and the Public Policy Exception: Solving the Foreign Judgment Quandary by Way of Tribal Courts" (2004) 153 University of Pennsylvania Law Review 797 (arguing for the adoption of an international "constitution-like" document to establish international standards of public policy, by analogy with the relationship between the United States federal government and tribal nations).

${ }^{68}$ See generally Wahab, MSA, "Cultural Globalization and Public Policy: Exclusion of Foreign Law in the Global Village" in Freeman, M (ed), Law and Sociology (2005) 8 Current Legal Issues 360; Mosconi, F, "Exceptions to the Operation of Choice of Law Rules" (1989-V) 217 Recueil des Cours 9 at p.67ff; Burger, DC, "Transnational Public Policy as a Factor in Choice of Law Analysis" (1984) 5 New York Law School Journal of International and Comparative Law 370; Dolinger, J, "World Public Policy - Real International Public Policy in the Conflict of Laws" (1982) 17 Texas International Law Journal 167.

${ }^{69}$ Kuwait Airways Corporation v Iraqi Airways Co \& Anor [2002] UKHL 19 at [114], per Lord Steyn.

${ }^{70}$ See Lagarde, P, "Public Policy", Chapter 11, in Lipstein, K (ed), International Encyclopedia of Comparative Law, Vol III: Private International Law (1994) at [55ff]; Benvenisti, E, "Judicial Misgivings Regarding the Application of International Law: An Analysis of Attitudes of National Courts" (1993) 4 European Journal of International Law 159 at pp.171-2; German section, p.12ff, in Rubino-Sammartano, M and Morse, CGJ (eds), "Public Policy in Transnational Relationships" (loose leaf, 1991ff).

${ }^{71}$ See, eg, World Duty Free Company Ltd v Kenya, ICSID ARB/00/7 (Award, 4 October 2006) at [138157], and references therein (focusing on the international public policy against bribery and corruption); McDougall, A, "International Arbitration and Money Laundering” (2005) 20 American University International Law Review 1021 at p.1042ff; Gaillard, E and Savage, J, "Fouchard, Gaillard and Goldman on International Commercial Arbitration" (1999) at p.860ff, p.953ff; Craig, Park and Paulsson, "International Chamber of Commerce Arbitration" (3rd edn, 2000) at p 338ff; Lagarde, P, "Public Policy", Chapter 11, in Lipstein, K (ed), International Encyclopedia of Comparative Law, Vol III: Private International Law (1994) at [57]; Lalive, P, “Transnational (or Truly International) Public
} 
values but does not involve the submission of the arbitration to any particular national $\operatorname{order}^{72}$.

Fourth and finally, public policy can also exceptionally possess an absolute character where it is derived not from international norms, but from an essential national interest. Such cases must necessarily be rare, but explain the use of public policy to prevent enforcement of a contract which may aid an enemy state during a time of $\operatorname{war}^{73}$.

In practice a norm will rarely belong indisputably to any of these four categories - its relativity will almost always be a question of degree. Public policy may be basically shared between two states, but with some level of continued disagreement about its exact scope of application. Another factor which must be considered in evaluating the relativity of a norm is the degree of tolerance of difference in the interpretation and application of the policy - what human rights scholars call the 'margin of appreciation' of the norm. Norms which are more open to differing interpretations, which leave a greater degree of discretion to states to determine the manner and scope of their implementation, are necessarily less capable of being absolute than norms which establish a clear and fixed prohibition. In the former case, there is a greater scope for states to adopt positions which are different but equally consistent with underlying public policy.

All these points lead towards a single conclusion. The extent to which a public policy is shared or absolute (ought to be shared) determines the degree of relativity of the public policy concerned. The less the public policy is shared, or the greater the relativity of the public policy, the harder it is to justify its application as an 'intolerant' exception to the normal rules on the application of foreign law or the recognition and enforcement of foreign judgments.

The possibility of shared or absolute public policy does not merely affect the justifiability of an application of public policy. Where public policy possesses this character, it transforms the effect of the public policy exception itself. Where the public policy is (actually or putatively) accepted in all the affected states, it cannot be argued that it is being used as a mechanism to impose domestic policies. A finding that the foreign law is contrary to public policy involves, in effect, a finding that the foreign law is contrary to the public policy of the foreign state itself, and thus the public policy should be applied in preference to the foreign law. It therefore does not undermine the systemic objectives of private international law. There is no question of intolerance of difference, given that there is at least a belief in an essential unity of policy. Public policy becomes instead a mechanism through which other norms are made to prevail over the policies inherent in private international law. It operates as a

\footnotetext{
Policy and International Arbitration", in Sanders, P (ed), Comparative Arbitration Practice and Public Policy in Arbitration (1986) at p.257ff (and other articles at p.177ff).

${ }^{72}$ Arbitrators may, of course, also take into consideration the public policy of the state or states where an award is likely to be enforced, in order to ensure that it is effective.

${ }^{73}$ Dynamit v Rio Tinto [1918] AC 260; Robson v Premier Oil and Pipe Line Co [1915] 2 Ch 124. In Lorentzen $v$ Lydden \& Co [1942] 2 KB 202 the public policy of supporting wartime allies was used to justify the application of foreign law contrary to the usual choice of law rule, but this 'positive' role for public policy was disapproved of in Bank voor Handel v Slatford [1951] 2 All ER 779.
} 
form of flexibility in the application of choice of law or judgment recognition and enforcement rules, without undermining the universality of the rule system.

The application of shared or absolute public policy is thus not a 'horizontal' assertion of the policies of one state over another; it is a 'vertical' assertion of one policy over another, within a legal order. It involves a claim concerning the hierarchy of norms, not a claim concerning the relative superiority of the content of the norms. It is not a negative argument for rejection of the application of foreign law, but a positive argument for flexibility in choice of law rules to allow them to reflect other shared or international policies ${ }^{74}$. Accepting public policy in this context is thus consistent with the conceptualisation of public policy from a constitutional perspective, discussed above. If public policy is adopted in a context in which it is shared or absolute, it does not involve an exercise of judicial discretion contrary to the policies of the state, but an indirect method of giving effect to those policies; it is not an imposition of the norms of one state on another, but a method of prioritising one norm (which may itself be international) over another ${ }^{75}$.

Thus, the scope of application of a public policy should depend not merely on the degree of local connection with the dispute, but on the degree of relativity of the norm of public policy which is being considered. Where the public policy is strongly relative, a high degree of proximity between the dispute and the forum state will be necessary to justify its application. Where the public policy is shared or absolute, there is no need to limit its application, because it does not involve an implicit choice or prioritisation of local norms, and thus is qualitatively distinct from the intolerance involved in an application of merely local policy ${ }^{76}$.

This understanding of public policy reveals, however, another reason why public policy may be limited even in the context of a shared or absolute norm. Where public policy applies in this way, the application of the policy becomes a question of enforcement of shared norms, a method of ensuring the compliance of the foreign legal order with norms applicable to it. But it is not clear that it will always be acceptable for the courts of one state to evaluate the compliance of a foreign law or the judgment of a foreign court with a shared policy, particularly if other mechanisms of ensuring compliance exist.

For example, it has been argued that a judgment from a state which is a party to the ECHR, obtained in breach of rights established under the ECHR and being enforced in another Convention state, should be refused recognition on the grounds of public policy regardless of the proximity of the dispute with the forum, because the values

\footnotetext{
${ }^{74}$ Dolinger, J, "World Public Policy - Real International Public Policy in the Conflict of Laws" (1982) 17 Texas International Law Journal 167 at p.177.

${ }^{75}$ It therefore does not depend on a 'monist' conception of international law as directly applicable in English law or as having priority over domestic rules or policies: see, eg, Mosconi, F, "Exceptions to the Operation of Choice of Law Rules" (1989-V) 217 Recueil des Cours 9 at p.68ff; Mann, FA, "The Consequences of an International Wrong in International and National Law" (1976-7) 48 British Yearbook of International Law 1.

${ }^{76}$ See generally Mann, FA, "The Consequences of an International Wrong in International and National Law" (1976-7) 48 British Yearbook of International Law 1 at p.28ff (arguing against the use of public policy to give effect to international law, out of concern that it may be inappropriately restricted).
} 
which are applied here are shared, and equally applicable in both states ${ }^{77}$. However, it might equally be suggested that the application of public policy should be restricted to reflect the requirements of mutual respect and trust between Member States, and the priority of the European Court of Human Rights as a mechanism for enforcing ECHR standards ${ }^{78}$. Thus, it may be argued that the courts of Convention states should, at least in some circumstances, refrain from reviewing decisions of other states for compliance with ECHR rights, unless the breach is so serious that the need to remedy the breach outweighs the need to respect the usual procedures. This provides the best explanation for the hesitancy expressed by the courts in permitting public policy to be used in this way - here, the limits on public policy do not derive from the proximity of the dispute or the degree of relativity of the applicable norms, but from the context of mutual trust and institutional deference.

In summary, a further dimension of the application of public policy is the degree of relativity of the norm. The greater the relativity of the norm, the more its application involves an intolerance of difference in foreign law, and the less easily courts should be prepared to apply it. Norms which are absolute or shared between states should ordinarily be more freely applied by courts, but even these may be limited by considerations of mutual trust and deference to alternative mechanisms for the enforcement of the norms.

\subsection{Seriousness of the breach}

Another related consideration for the invocation of public policy is the seriousness of the breach of the norm. A norm may be violated in a minor, technical way, or through a fundamental breach. For some norms, there will be more obvious degrees of violation. For example, the fact that a foreign court has awarded greater damages than would be awarded by an English court would not of itself be grounds for refusing recognition and enforcement of the foreign judgment. However, if a hugely excessive amount of damages were awarded in foreign proceedings, English courts would be likely to refuse recognition on the grounds of public policy. The question of how excessive the award needs to be before it becomes contrary to public policy is obviously a question of degree. Similarly, although English law dictates a minimum age of 16 for getting married, a foreign marriage of two 15 year olds is much less likely to justify the application of public policy than an arranged marriage of two much younger children. Thus, the seriousness of breach of a norm is itself in many cases a further dimension of analysis for the application of public policy in private international law. The more serious the breach, the more likely and the more acceptable it becomes that public policy may be invoked against the breach.

\footnotetext{
${ }^{77}$ Maronier v Larmer [2003] QB 620 (suggesting that this may only be available in cases of breach of ECHR procedural standards, not in case of suggested non-compliance with substantive law); see also Citibank NA v Rafidian Bank \& Anor [2003] EWHC 1950.

${ }^{78}$ See Krombach v Bamberski [2000] ECR I-0000, Case C-7/98 (discussed in section 4.2 below); Régie Nationale des Usines Renault v Maxicar [2000] ECR I-2973, Case C-38/98.
} 


\section{Mapping the principled application of public policy in private international law}

\subsection{Diagrammatical representation}

Three elements of public policy have been identified - the degree of proximity between the dispute and the forum, the degree of relativity of the policy norm, and the seriousness of the breach of that norm. Public policy should be more likely to be invoked if there is a strong connection with the forum, the norm is shared or absolute, and the breach is serious. Public policy should be less likely to be invoked if the forum has little interest in the dispute, the norm is more relative, and the breach is minor. These elements can be interpreted as three dimensions of public policy, and thus represented as a 'map' which indicates the circumstances in which public policy is or ought to be applicable (Figure 1). Thus, public policy becomes applicable the greater the proximity of the dispute with the forum state, the greater the extent to which the affected norm possesses a shared or absolute character (the lower its relativity), and the greater the seriousness of the breach.

\section{Figure 1}

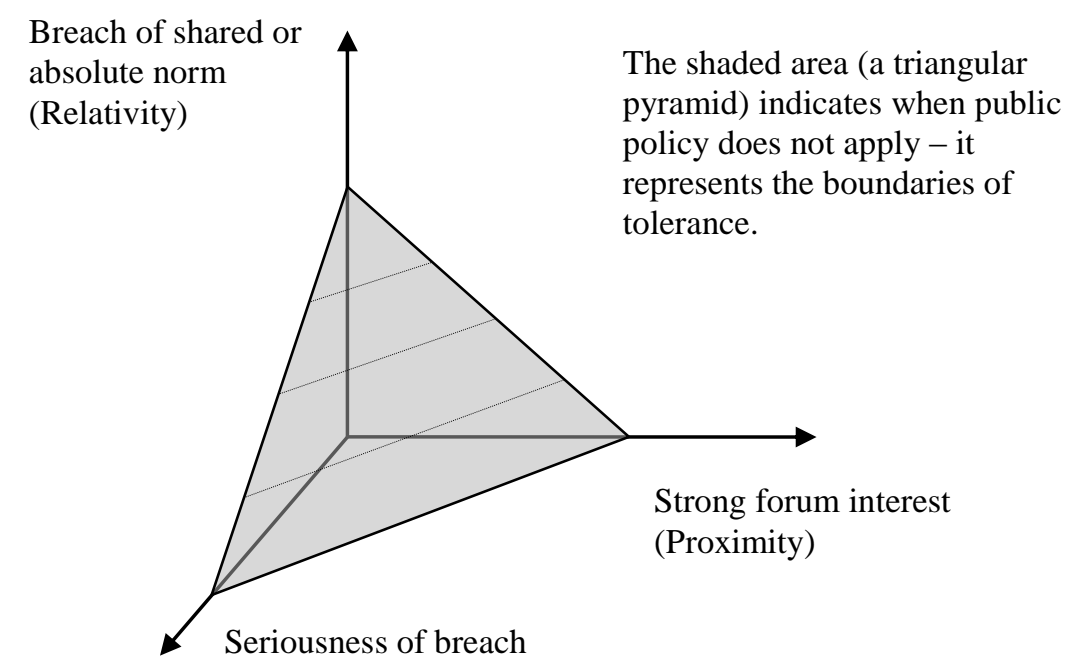

The next stage in this examination of public policy is to test the practice of the English courts against this analytical framework. It may readily be observed that courts in general, and particularly common law courts, do not always appear to analyse these issues clearly, and an element of interpretation is thus necessary. Nevertheless, it will be argued that the practice of the English courts has been broadly consistent with the principles developed above.

For the sake of simplicity and ease of illustration, in the following analysis only two of these factors will be examined - first, the proximity of the dispute, and second, the relativity of the norms. This can be represented as a 'cross-section' of Figure 1, in two dimensions (Figure 2). In the analysis to follow, five different categories of cases will be distinguished, indicated on the diagram with the appropriate letter. 


\section{Figure 2}

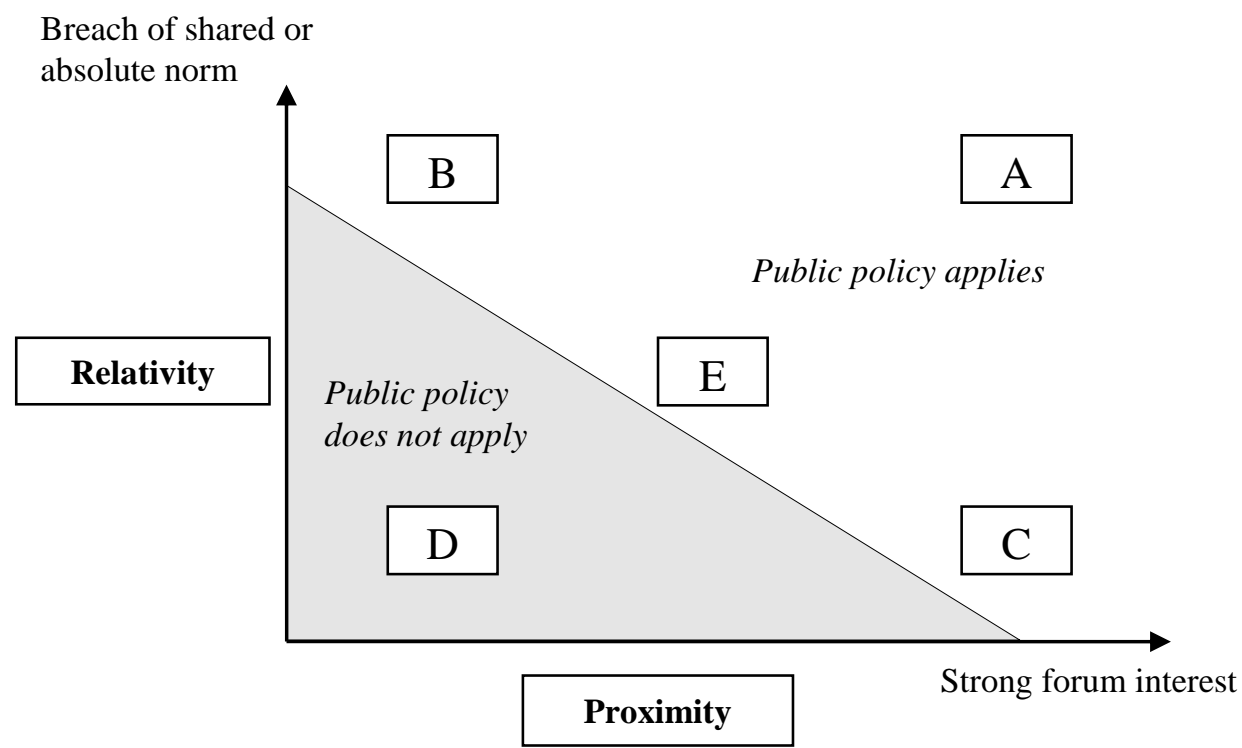

Of course this analysis is not intended to suggest that real life cases, including the cases considered below, fit neatly into these categories. Any case may, however, be located somewhere on this diagram, and this placing will suggest whether public policy should or should not be invoked. The determination of where a case fits into the diagram itself involves elements of judgment, of evaluation of the facts. Nevertheless, analysing public policy through these policy dimensions does, it is argued, represent a significant advance on its traditional characterisation as discretionary.

\subsection{Category A - Proximate disputes and shared or absolute policies}

The first category of cases to be examined is perhaps the easiest. These are cases in which the dispute is proximate to the forum (the forum has a strong interest in the dispute) and the policies which are at stake are shared with the other affected states or are absolute (and thus ought to be shared). The case law is consistent with the expectation that public policy should be readily applied in these circumstances.

One of the oldest recorded English cases of the application of public policy falls clearly into this category. In Somerset's case $(1772)^{79}$, a slave purchased in Virginia by a Virginia resident was brought to England, escaped and was recaptured. An application was made to the English court for his release. Lord Mansfield noted that property rights in a slave were recognised under the law of Virginia, observing that "the power of a master over his slave has been exceedingly different, in different countries". However, particularly given the presence of the slave in England ${ }^{80}$, he was prepared to apply the English public policy against slavery to refuse application of

\footnotetext{
${ }^{79}$ Somerset $v$ Stewart (1772) 20 State Trials 1

${ }^{80}$ Note the much later decision enforcing a contract for the sale of slaves in Brazil in Santos v Illidge (1860) 8 CBNS 861, suggesting that the policy against slavery remained somewhat relative.
} 
that law, holding that "the state of slavery is of such a nature, that it is incapable of being introduced on any reasons, moral or political".

The case of Oppenheimer $v$ Cattermole $(1976)^{81}$ is perhaps the prototypical case for the application of public policy. This dispute involved a claim by Oppenheimer, a Jewish émigré from Nazi Germany who had acquired English nationality, in respect of his liability for UK income tax. The dispute was therefore highly proximate to England. It turned on the question of whether he had also retained his German nationality, which had been purportedly stripped from him by a 1941 German law on the grounds of his race - an act clearly contrary to both English and international policies against racial discrimination. The court held that "it is part of the public policy of this country that our courts should give effect to clearly established rules of international law"82, emphasising their preparedness to give effect to public policy which possesses this absolute character, and thus refused to recognise the effect of the discriminatory German law $^{83}$. This decision is consistent with other cases in which the courts have refused to apply a foreign law where it is viewed as contrary to international law ${ }^{84}$.

A more recent decision which illustrates the role of public policy in this type of situation is the European Court of Justice case of Krombach v Bamberski $(2001)^{85}$.

Krombach, domiciled in Germany, was both criminally prosecuted and subject to civil proceedings in France following the death of a French girl in Germany. Under French procedural rules, his failure to appear in the criminal proceedings prevented him from presenting a defence in the civil proceedings. The issue was whether the French civil judgment should be enforceable in Germany under the Brussels Convention (1968) ${ }^{86}$. From the perspective of the German court, this was clearly a proximate dispute, involving a claim against a German domicile in respect of conduct in Germany. Further, it was held that the French court's procedural rule which denied the defendant the opportunity to present a defence was a "manifest breach of a fundamental right" under the European Convention on Human Rights ${ }^{87}$ - a policy

\footnotetext{
${ }^{81}$ Oppenheimer v Cattermole [1976] AC 249.

${ }^{82}$ At p. 278.

${ }^{83}$ Although the conclusion of the court was ultimately that the claimant had lost his German nationality for other reasons.

${ }^{84}$ See, eg, Anglo-Iranian Oil v Jaffrate (“The Rose Mary") [1953] 1 WLR 246 (Supreme Court of Aden, refusing to recognise proprietary effects of an Iranian law purporting to nationalise foreign owned oil in Iran, on the grounds that nationalisation of foreign owned property without compensation is contrary to international law). The judgment in the English case of In re Claim by Helbert Wagg \& Co Ltd [1956] Ch 323 doubted some of the reasoning in the former case, but accepted that public policy, which may require reference to international law, provided a limit on the ordinary application of foreign law as the lex situs in proprietary questions. See further Novello and Co $v$ Hinrichsen Edition [1951] 1 All ER 779 (refusing to recognise a German law forcing an undervalued sale of Jewish property); Frankfurther $v$ W L Exner Ltd [1947] Ch 629; Re Fried Krupp Actien-Gesellschaft [1917] 2 Ch 188 (refusing to apply a German law held (at p.194) to be "not conformable to the usage of nations"); Wolff v Oxholm [1814-23] All ER Rep 208. In De Wutz v Hendricks (1824) 2 Bing 314 a contract governed by English law was similarly held invalid on the grounds that it was contrary to the 'law of nations'.

${ }^{85}$ Krombach v Bamberski [2000] ECR I-0000, Case C-7/98.

${ }^{86}$ Convention of 27 September 1968 on Jurisdiction and the Enforcement of Judgments in Civil and Commercial Matters, OJ C 27, 26.1.1998.

${ }^{87}$ Krombach v Bamberski [2000] ECR I-0000, Case C-7/98 at [40].
} 
clearly shared between France and Germany ${ }^{88}$. The European Court of Justice, while confirming previous authority to the effect that the public policy exception to the Brussels Convention must only be applied in exceptional cases ${ }^{89}$, reflecting at least in part the need for institutional deference discussed above ${ }^{90}$, held that it was open to the German court to apply public policy in these circumstances to prevent the enforcement of the French civil judgment in Germany ${ }^{91}$. On the analysis in this article, the fact that the public policy was both shared between the affected states and proximate to the forum state strongly justifies this conclusion ${ }^{92}$.

\subsection{Category B - Low proximity disputes but shared or absolute policies}

In the second category of cases, the dispute is not closely connected to the forum state, but the policies which are at stake are (or, it is believed ought to be) shared between the affected states. The case law is consistent with the conclusion that a strongly shared or absolute policy may be applied, regardless of the low proximity of the dispute.

The application of this principle is clearly illustrated by the recent case of Kuwait Airways Corporation v Iraqi Airways (2002) ${ }^{93}$. This dispute involved various claims concerning the ownership of aircraft which had been seized by Iraqi authorities from the claimants in the territory of Kuwait, at the time of the Iraqi invasion in 1990. Once seized, the aircraft had been taken to various locations in Iraq. The central issue was whether the English courts should recognise and give effect to a subsequent Iraqi law which purported to nationalise the aircraft. Ordinarily, an English court would recognise the proprietary effects of a nationalisation of property present on the territory of the nationalising state - the court will apply the lex situs of the property to determine ownership of the property. However, the court noted that "a provision of foreign law will be disregarded when it would lead to a result wholly alien to fundamental requirements of justice as administered by an English court" ${ }^{\prime 94}$. The court noted that the "seizure and assimilation were flagrant violations of rules of international law of fundamental importance" "95, and thus held that "enforcement or

\footnotetext{
${ }^{88}$ The European Court of Justice has also held that certain principles of European competition law constitute national public policy for the purposes of justifying the non-enforcement of an arbitral award: Eco Swiss China Time v Benetton International [1999] ECR I-3055. But see Régie Nationale des Usines Renault v Maxicar [2000] ECR I-2973, Case C-38/98, finding (at [32]) that "the fact that the alleged error concerns rules of Community law does not alter the conditions for being able to rely on the clause on public policy. It is for the national court to ensure with equal diligence the protection of rights established in national law and rights conferred by Community law". On European public policy see generally Meidanis, HP, "Public Policy and Ordre Public in the Private International Law of the EU: Traditional Positions and Modern Trends" (2005) 30 European Law Review 95; Muir Watt, H, "Evidence of an Emergent European Legal Culture: Public Policy Requirements of Procedural Fairness Under the Brussels and Lugano Conventions" (2001) 36 Texas International Law Journal 539.

${ }^{89}$ See, eg, Hendrikman and Feyen $v$ Magenta Druck \& Verlag [1996] ECR I-4943; Solo Kleinmotoren v Boch [1994] ECR I-2237; Hoffmann v Krieg [1988] ECR 645, Case R-145/86.

${ }^{90}$ See section 3.3 above.

${ }^{91}$ The case went back to the German courts, which confirmed the application of public policy, and there were also proceedings before the European Court of Human Rights: for further detail see, eg, Lowenfeld, AF, "Jurisdiction, Enforcement, Public Policy and Res Judicata: The Krombach Case", in Einhorn, T and Siehr, K (eds), Intercontinental Cooperation Through Private International Law: Essays in Memory of Peter E. Nygh (2004).

${ }^{92}$ See also Maronier v Larmer [2003] QB 620.

${ }^{93}$ Kuwait Airways Corporation v Iraqi Airways Co \& Anor [2002] UKHL 19.

${ }^{94}$ At [16], per Lord Nichols.

95 At [20], per Lord Nichols.
} 
recognition of this law would be manifestly contrary to the public policy of English law" "96. The court thus concluded that "a legislative act by a foreign state which is in flagrant breach of clearly established rules of international law ought not to be recognised by the courts of this country as forming part of the lex situs of that state" 97 - one judge describing the case as "a paradigm of the public policy exception"98.

What of the fact that the case concerned events and property located entirely outside England? Lord Hope noted that:

"There is nothing in this case which connects the laws of this country with the events constituting the alleged tort, other than the fact that this is the country where the proceedings were brought. As my noble and learned friend Lord Scott of Foscote has observed, this is an action in tort that has nothing whatever to do with England. So I would have no difficulty in holding that, in a case of this kind, a principle of English public policy which was purely domestic or parochial in character would not provide clear and satisfying grounds for disapplying the primary rule which favours the lex loci delicti." 99

This clearly acknowledges the potential role of the principle of proximity in limiting the application of public policy. But Lord Hope also held that an absolute form of public policy could be applied regardless of proximity when he went on to conclude that:

"the public policy objection which is raised in this case is plainly not of that character. It is based on the Charter of the United Nations and the resolutions which were made under it. ... There is a clear point of contact between this part of the lex loci delicti and the breaches of international law to which our courts are entitled to decline to give effect on grounds of public policy."100

In a dispute with very low proximity to England, the court was nevertheless prepared to invoke an absolute public policy, derived here from international law, to refuse to apply or give effect to a foreign law that would ordinarily be applicable under English choice of law rules. Other cases have similarly suggested that public policy may be readily applicable where the foreign law is "morally repugnant"101 "offensive to the conscience of the English court"102, or "violates some moral principle, which, if it is not, ought to be universally recognised"103. It has long been accepted that "where a

\footnotetext{
${ }^{96}$ At [29], per Lord Nichols.

${ }^{97}$ At [148], per Lord Hope.

98 At [114], per Lord Steyn.

${ }^{99}$ At [166], per Lord Hope.

100 At [167], per Lord Hope.

${ }^{101}$ Glencore International v Metro Trading International [2001] 1 Lloyd's Rep 284 at 295 (refusing to apply public policy to invalidate a transfer of property which was valid under the lex situs).

${ }^{102}$ Cheni v Cheni [1965] P 85 at 99 (refusing to apply public policy to invalidate a marriage between an uncle and niece which was lawful under Egyptian law but would have been unlawful under English law); see similarly Armitage v Nanchen (1983) 4 FLR 293 (refusing to apply public policy to invalidate a foreign paternity determination on the grounds that the foreign procedures, while not compliant with English standards, did not "constitute an infraction of the rules of natural justice in the eye of the English court" (at p.300)).

${ }^{103}$ Kaufman v Gerson [1904] 1 KB 591 (applying public policy to refuse to recognise a contract entered into under duress in France, regardless of whether it was enforceable under French law); see similarly In re Meyer [1971] P 298 (applying public policy to refuse to recognise a divorce entered into
} 
contract is void on the ground of immorality, or is contrary to such positive law as would prohibit the making of such a contract at all, then the contract would be void all over the world, and no civilised country would be called on to enforce it"104.

These principles are further illustrated, albeit in a slightly different context, in the case of Lemenda Trading Co Ltd v African Middle East Petroleum Co Ltd (1988) ${ }^{105}$. The plaintiffs in this case sought to claim a commission under a contract in which they undertook to assist the respondents in procuring a deal for the supply of oil from Qatar (by influencing government officials). The court concluded that, if the dispute were litigated in Qatar, the contract would be void as contrary to the public policy of Qatar. The court also concluded that if the contract were to be performed in England, it would have been contrary to English public policy. But was it contrary to English public policy to enforce a contract to be performed in Qatar? The court noted that:

"Some heads of public policy are based on universal principles of morality. ... Where a contract infringes such a rule of public policy the English court will not enforce it, whatever the proper law of the contract and wherever the place of performance. Other principles of public policy may be based on considerations which are purely domestic. In such a case there would seem no good reason why they should be a bar to the enforcement of a contract to be performed abroad."106

Thus, the court acknowledged the effect of the relativity of the norm on the application of public policy in private international law. Here, the court concluded that "it is questionable whether the moral principles involved are so weighty as to lead an English court to refuse to enforce an agreement regardless of the country of performance and regardless of the attitude of that country to such a practice" 107 . Thus, it rejected the characterisation of the norm as possessing an absolute character. However, the court noted that:

"In the present case Qatar, the country in which the agreement was to be performed and with which, in my view, the agreement had the closest connection, has the same public policy as that which prevails in England. ... In my judgment, the English courts should not enforce an English law contract which falls to be performed abroad where (i) it relates to an adventure which is contrary to a head of English public policy which is founded on general principles of morality and (ii) the same public policy applies in the country of performance so that the agreement would not be enforceable under the law of

under duress in Nazi Germany). The decision of Israel Discount Bank of New York v Hadjipateras [1983] 3 All ER 129 casts some doubt on whether duress really possesses the character of an absolute norm - in this case the English courts refused to apply public policy to prevent enforcement of a New York judgment based on a guarantee purportedly obtained under duress, because the defence had not and might have been raised before the New York court. But Royal Boskalis Westminster v Mountain [1999] QB 674 suggests that it is a question of degree, with the most serious forms of duress having the character of "moral principles which ought to be universally recognised" (p.725), which would thus not only form part of English public policy, but would be presumed to be part of French public policy.

${ }^{104}$ In re Missouri Steamship Co (1888) 42 Ch D 321 at 336 (a case in which the contract was, in fact, governed by English law, and thus no English public policy concern strictly arose).

${ }^{105}$ Lemenda Trading Co Ltd v African Middle East Petroleum Co Ltd [1988] 1 All ER 513.

106 At p.521.

107 At p.523. 
that country. In such a situation international comity combines with English domestic public policy to militate against enforcement." 108

Thus, the fact that the public policy was shared was sufficient to justify its application. This is, of course, not a case of public policy being used in the context of the application of a foreign law or the recognition of a foreign judgment - the case concerned the validity of a contract. However, the principles which it establishes seem equally applicable in the context of public policy in private international law. Despite the lack of forum proximity with the dispute, the concordance of public policy between the forum state and the state in which the events giving rise to the dispute occurred had the effect that the English courts were justified in applying public policy.

\subsection{Category $\mathrm{C}$ - Relative policies but proximate disputes}

The next category of cases is those in which the claim involves a breach of a relative norm, but the dispute is strongly connected to the forum state. Here, the analysis in this article suggests that the application of public policy may be justifiable on the grounds of the strong proximity of the dispute to the forum.

Here we may consider, for example, the approach taken by the English courts to the question of validity of a foreign divorce which is lawfully obtained under foreign law, but not consistent with English law. Where the divorce is granted in a foreign state between two parties who are domiciled in that state, that is, where the dispute has a low proximity to England, the courts have not been prepared to apply English public policy to refuse recognition of the divorce ${ }^{109}$. Such cases fall within the scope of Category D, discussed below. Where, by contrast, one of the parties has an English domicile, the courts have refused recognition of the divorce through application of English public policy ${ }^{110}$. The justification for the application of public policy in one context and not in the other is clearly the differing proximity of the dispute.

Other examples of this distinction may readily be identified in the practice of the English courts. A polygamous marriage ${ }^{111}$ entered into by parties domiciled in a foreign state under which such a marriage is lawful will not be refused recognition if the parties subsequently move to England ${ }^{112}$, but would be contrary to English law

\footnotetext{
108 At p.523.

${ }^{109}$ See, eg, El Fadl v El Fadl [2000] 1 FLR 175 (refusing to apply public policy to invalidate a Talaq divorce procedure contrary to English public policy but consistent with Lebanese law, between two parties domiciled in Lebanon, holding (at p.190) that "comity between nations and belief systems requires ... that one country should accept the conscientiously held but very different standards of another where they are applied to those who are domiciled in it"). See similarly $K v R$ [2007] EWHC 2945 (Fam); H v H [2006] EWHC 2989 (Fam); Qureshi v Qureshi [1972] Fam 173.

${ }^{110}$ See, eg, Chaudhary v Chaudhary [1984] 3 All ER 1017 (in which a Talaq divorce was refused because the husband had obtained an English domicile). English courts have similarly applied public policy to refuse recognition of a Maltese decree declaring a valid English marriage between English domiciles to be void, despite the subsequent change in domicile of the husband (and thus, under the law at the time, his wife) to Malta: see Gray v Formosa [1963] P 259.

${ }^{111}$ For a critical perspective on the application of public policy in the context of marriage, see Murphy, J, "Rationality and Cultural Pluralism in the Non-Recognition of Foreign Marriages" (2000) 49 International and Comparative Law Quarterly 643.

112 The Matrimonial Proceedings (Polygamous Marriages) Act 1972 introduced the rule that a polygamous marriage is recognised for the purposes of matrimonial relief; such a marriage is also recognised for the purposes of succession (see, eg, Coleman v Shang [1961] AC 481); see also
} 
and public policy if entered into in England ${ }^{113}$ or by an English domicile ${ }^{114}$. Similarly, an agreement to commit champerty, governed by a foreign law under which it is valid, is nevertheless contrary to the public policy of England if it refers to proceedings to take place in England ${ }^{115}$, but not if it refers to proceedings to take place in a state which permits such agreements ${ }^{116}$. In Rousillon $v$ Rousillon $(1880)^{117}$, an undertaking of non-competition entered into in France and governed by French law was nevertheless potentially subject to the limits of English public policy because it extended to English territory and was allegedly breached in England ${ }^{118}$.

Some civil law systems have developed formalised doctrines which, reflecting this perspective, embody the idea of self-restraint in the imposition of domestic public policy in private international law disputes - doctrines which might profitably be adapted into English law. In French and Belgian law, public policy is limited or 'attenuated' (given an effet atténué), to reflect the degree of connection between the dispute and the forum state, the 'proximity' of the dispute ${ }^{119}$. In German, Austrian and Swiss law, public policy is limited under a doctrine known as Inlandsbeziehung or Binnenbeziehung, which provides that the application of public policy should vary depending on the domestic effects which the dispute has in the forum state ${ }^{120}$. The greater the effect within the state of the regulation of the legal relationship, the stronger the domestic effects of the case, the more likely that public policy is to be applied.

Onobrauche v Onobrauche [1978] 8 Fam Law 107 (finding that a husband had not committed adultery by virtue of having sexual relations with multiple wives to which he was lawfully married under foreign law). In Mohamed $v$ Knott [1969] 1 QB 1 a potentially polygamous Nigerian marriage between a girl of 13 and a man of 25 who subsequently moved to England was not found to be contrary to English public policy; see similarly In Re Bozzelli's Settlement [1902] 1 Ch 751.

113 See, eg, $A-M v A-M$ [2001] 2 FLR 6.

${ }^{114}$ Matrimonial Causes Act 1973 s.11(d); see, eg, Hussain v Hussain [1983] Fam 26; Risk v Risk [1951] P 50.

115 Trendtex Trading Corpn v Credit Suisse [1982] AC 679; In re Trepca Mines Ltd (No 2) [1963] Ch 199; Grell v Levy (1864) 16 CBNS 73. These cases may alternatively be justified by the argument that the assignability of the chose in action (the right to litigate) is governed by the lex situs of the property, that is, English law.

116 In re Trepca Mines Ltd (No 2) [1963] Ch 199 at 218; compare the Canadian decision in National Surety Co v Larsen [1929] 4 DLR 918.

${ }^{117}$ Rousillon v Rousillon (1880) 14 Ch D 351.

118 At p.369.

${ }^{119}$ Bureau, D and Muir Watt, H, "Droit international privé" (vol.1, 2007) at pp.255, 458ff; Mayer, P and Heuzé, V, "Droit international privé" $\left(9^{\text {th }}\right.$ edn, 2007) at pp.151ff, 282ff; Meidanis, HP, "Public Policy and Ordre Public in the Private International Law of the EU: Traditional Positions and Modern Trends" (2005) 30 European Law Review 95 at p.97; Enonchong, N, "Public Policy in the Conflict of Laws: A Chinese Wall Around Little England?” (1996) 45 International and Comparative Law Quarterly 633 at p.659-60; Lagarde, P, "Public Policy”, Chapter 11, in Lipstein, K (ed), International Encyclopedia of Comparative Law, Vol III: Private International Law (1994) at [46ff]; Bucher, A, "L'ordre public et le but social des lois en droit international privé" (1993-II) 239 Recueil des Cours 9 at p.47ff; Mosconi, F, "Exceptions to the Operation of Choice of Law Rules" (1989-V) 217 Recueil des Cours 9 at p.87ff.

${ }^{120}$ Lagarde, P, "Public Policy", Chapter 11, in Lipstein, K (ed), International Encyclopedia of Comparative Law, Vol III: Private International Law (1994) at [26ff]; Bucher, A, "L'ordre public et le but social des lois en droit international privé" (1993-II) 239 Recueil des Cours 9 at p.52ff; Mosconi, F, "Exceptions to the Operation of Choice of Law Rules" (1989-V) 217 Recueil des Cours 9 at p.98ff. 
Although, as noted above ${ }^{121}$, modern open textured approaches to choice of law in the United States tend to subsume public policy concerns within choice of law rules, at least historically most case law in the United States can be interpreted to similar effect $^{122}$. In the seminal decision of Home Insurance $v$ Dick $(1930)^{123}$, a Texan court was not permitted to apply the law or the public policy of the forum to replace the otherwise applicable law of Mexico, because it did not have a sufficient connection with the dispute. Basing its reasoning on an analysis of the Due Process clause of the United States Constitution, the Supreme Court held that the public policy of Texas "may not abrogate the rights of parties beyond its borders having no relation to anything done or to be done within them"124.

These are all, in reality, only slightly different formulations of one idea. Where a dispute governed by foreign law is nevertheless very closely connected to the forum state, local public policy may be applied relatively freely. Where the dispute is only connected in a very limited way ${ }^{125}$, the justification for applying local public policy is weaker. The application of national public policy to international disputes governed by foreign law should be limited according to the degree of connection, the proximity, of the proceedings and the forum state.

\subsection{Category $D$ - Low proximity disputes and relative policies}

A further category concerns cases which involve both disputes with a low proximity and breaches of only relative norms. As these cases lack either criteria which justifies the application of public policy ${ }^{126}$, it is to be expected that in these cases courts should be most prepared to accept that a foreign law or judgment should be given effect, even if the result is one which is different from that which would be reached under English law. They should thus be cases in which the English courts refuse to apply public policy.

The case of Saxby $v$ Fulton (1909) ${ }^{127}$ is an illustration of the application of these principles. This case concerned the enforcement of a loan agreement entered into in Monte Carlo, for the purposes of procuring money for gambling. Such an agreement would have been invalid if entered into in England at the time, as contrary to English public policy. The question therefore arose whether it should be refused enforcement in England. Here, however, the dispute was largely unconnected with England - the agreement was entered into in Monte Carlo, the contract was (according to English choice of law rules) governed by the law of Monte Carlo, and the central performance of the agreement, the provision of money as a loan, was to be effected there. The court concluded that it would not be contrary to English public policy to give effect to the law of Monte Carlo which permitted enforcement of a loan agreement for the purposes of gambling - that "there is nothing contrary to public policy in allowing the

\footnotetext{
${ }^{121}$ See section 3.2 above.

${ }^{122}$ See, eg, Paulsen, MG and Sovern, MI, "'Public Policy' in the Conflict of Laws" (1956) 56

Columbia Law Review 969; Nussbaum, A, "Public Policy and the Political Crisis in the Conflict of Laws" (1940) 49 Yale Law Journal 1027 at p.1031ff.

${ }^{123}$ Home Insurance v Dick (1930) 281 US 397.

${ }^{124}$ At p.410; see similarly Beach, JK, "Interstate Enforcement of Vested Rights" (1918) 27 Yale Law Journal 656 at p.662ff.

${ }^{125}$ It is, of course, unlikely to be wholly unconnected if the forum has jurisdiction.

${ }^{126}$ Unless the breach is very serious - see sections 3.4 and 4.1 above.

127 Saxby v Fulton [1909] 2 KB 208.
} 
enforcement of such a contract" 128 . While there was a clear principle of English public policy contrary to gambling contracts, it was held that "a betting or gaming contract in a country where betting or gaming is recognized by the law cannot be said to be contrary to essential principles of morality or justice" ${ }^{129}$. Thus, the public policy which was at stake was essentially acknowledged as possessing a relative character and an attenuated effect. This case was distinguished from those "cases in which an element is present which may be summarized as something contrary to the morality of civilized nations, as we understand it" 130 - instead, it was held that "there is nothing of that objectionable nature in a contract to lend money for the purpose of gambling"131. The relative character of the public policy at stake, together with the low proximity of the dispute with the forum state, meant that the application of English public policy was unjustified.

Another case which exemplifies these principles is In re Bonacina $(1912)^{132}$, which involved a unilateral undertaking, governed by Italian law, entered into in Italy by an Italian to pay a debt to another Italian. Such an undertaking would be enforceable according to Italian law, but would not be enforceable under English law because it lacked the consideration necessary to constitute a contractually binding obligation. Nevertheless, the English courts did give effect to the undertaking. Here again, the dispute was closely connected with Italy and not proximate to the forum state. The norm which was in dispute was clearly one with a relative character - the court observed that "the doctrine of consideration as it exists with us is peculiar to our common law; it is not to be found in the law of Italy or, so far as I am aware, in the law of other Continental countries which derive the principles of their jurisprudence in regard to contractual obligations from the Roman source" ${ }^{133}$. More generally, it was held that "a contract which is void (not being immoral) here may be perfectly good in a foreign country, and, if so, can be enforced here"134. Thus, in the absence of 'immorality' (and thus a breach of a more absolute policy), the English court was not prepared to apply public policy to exclude the application of foreign law to an essentially foreign dispute, an approach which is consistent with a number of other cases $^{135}$.

It was noted above ${ }^{136}$ that, if a dispute in the English courts involves the potential application of the law of a state bound by the European Convention on Human Rights or the recognition of a judgment from such a state, public policy derived from the ECHR would be shared and thus more freely applicable. Where, by contrast, a

\footnotetext{
128 At p.230, per Buckley LJ.

${ }^{129}$ At p.228, per Buckley LJ.

${ }^{130}$ At p.232, per Kennedy LJ.

131 At p.232, per Kennedy LJ.

${ }^{132}$ In re Bonacina [1912] 2 Ch 394

${ }^{133}$ At p.403, per Kennedy LJ.

${ }^{134}$ At p.402, per Farwell LJ.

135 See, eg, Addison v Brown [1954] 2 All ER 213 (refusing to apply public policy to invalidate an agreement entered into in California and accepted by the courts of California which ousted the jurisdiction of those courts, despite the fact that such an agreement would have been void if it purported to oust the jurisdiction of English courts); Shrichand \& Co v Lacon (1906) 22 Times LR 245 (refusing to invalidate a contract for money-lending contrary to English law which was entered into in India and to be performed in India); Sottomayor v De Barros [1874-80] All ER Rep 94 (refusing to apply public policy to prevent application of a foreign law invalidating a marriage, where the marriage, although it had taken place in England, was between two foreign domiciles).

${ }^{136}$ See section 3.3 above.
} 
judgment sought to be enforced from a non-Convention state is contrary to public policy derived from the ECHR which is not shared with that state, and the case lacks proximity with the forum, the English courts have, also consistently with the analysis in this article, indicated that only the most serious breaches might justify the invocation of public policy ${ }^{137}$.

\subsection{Category $\mathbf{E}$ - Intermediate cases}

The most difficult cases are those where there is some degree of proximity between the dispute and the forum state, but not so much that local public policy is very readily applicable, and the public policy at stake is not entirely shared or absolute, but neither is it entirely relative. Although in this context the application of public policy is more controversial and difficult to predict, the fact that 'hard cases' exist does not, of course, undermine the principles which have been articulated and illustrated in this article.

The case of Vervaeke $v$ Smith $(1983)^{138}$ provides an illustration of the difficulties in determining whether or not to apply public policy in such an intermediate situation. The facts of the case are notorious. Vervaeke, a Belgian prostitute, married Smith, an Englishman, in 1954, entirely in order to acquire British nationality. In 1970, she purported to marry an Italian in Italy, who, having died at their wedding reception, left an estate which included a large amount of English property. Vervaeke brought proceedings in England seeking to have her married to Smith declared void so that her second marriage would be valid, and hence she would inherit. Having failed in these English proceedings (initially brought on fraudulent grounds), she sought the same order in the courts of Belgium and succeeded, on the grounds that the marriage was contrary to Belgian public policy. The further English proceedings which followed were thus, finally, an attempt to obtain recognition and enforcement in the English courts of the Belgian judgment invalidating the English marriage. The English court refused to enforce the foreign judgment, principally on the ground that the issue was res judicata in the English courts (because of the prior English proceedings), but also on the alternative ground that it was contrary to English public policy.

The court noted that the issue arose because there were differing approaches in English and Belgian law to the question of the validity of a 'sham' marriage. English law favoured the certainty of validating any registered and formally correct marriage. Belgian law, by contrast, would invalidate the marriage on the grounds that it lacked genuine consent. This is thus clearly a situation in which there is at least a degree of relativity of public policy - the English policy is stronger than, for example, the doctrine of consideration, but clearly not an absolute moral compulsion. It is also clearly a situation in which the dispute is partly connected with England, is somewhat 'proximate', but also has strong connections with other jurisdictions. It is therefore no surprise that the dispute raised difficult issues of public policy.

\footnotetext{
${ }^{137}$ Government of the United States of America v Montgomery (No 2) [2004] UKHL 37 (refusing to apply public policy to prevent registration of a United States judgment obtained through procedures which would, if carried out in a Convention state, have been contrary to the ECHR). But see Pellegrini v Italy (2002) 35 EHRR 44; Kinsch, P, "The Impact of Human Rights on the Application of Foreign Law and on the Recognition of Foreign Judgments - A Survey of the Cases Decided by the European Human Rights Institutions", in Einhorn, T and Siehr, K (eds), Intercontinental Cooperation Through Private International Law: Essays in Memory of Peter E. Nygh (2004) at p.214ff.

${ }^{138}$ Vervaeke $v$ Smith [1983] 1 AC 145.
} 
The House of Lords, while acknowledging that public policy should only be invoked "with extreme reserve" 139 , nevertheless ultimately held (disagreeing with the decision at first instance and in the Court of Appeal) that the Belgian judgment did "offend the conscience of the court" 140 , and thus it would be contrary to English public policy to give it effect. This was, at least in part, based on the proximity of the dispute. Indeed, one member of the court argued expressly for the articulation of a type of proximity test, suggesting that the "criterion of a real and substantial connection seems to me to be useful and relevant in considering the choice of law for testing, if not all questions of essential validity, at least the question of the sort of quintessential validity in issue in this appeal - the question which law's public policy should determine the validity of the marriage"141. It was also suggested that if English choice of law rules would point to English law being applicable, the court should, on this reasoning, be more prepared to apply English public policy to refuse enforcement of a foreign judgment which had applied a different law. This is a clear illustration of the idea examined above $^{142}$ that public policy, as a special form of choice of law rule, should be under the same principled constraints which operate in the context of choice of law itself.

While it is true that much emphasis was placed on the fact that the Belgian judgment depended on Belgian public policy, and thus it was a case of competing public policies rather than a refusal to apply a judgment based on a foreign statute, this remains a good illustration of the principles analysed in this article. While it was not an obvious case, the reasonable degree of proximity, together with the reasonably strong commitment of the English courts to the relevant policy, together justified the application of English public policy to refuse enforcement of the foreign judgment.

\section{$5 \quad$ Wrongly decided cases?}

In the analysis thus far it has been demonstrated that the practice of the English courts in the use of public policy in private international law is broadly consistent with the principles developed in this article. These principles are, however, not merely intended to serve an explanatory function, or to provide guidance for future decisions. They are also intended to suggest constraints on the operation of public policy, and thereby to provide a basis on which to criticise its utilisation in some circumstances. As long as the exercise of public policy is characterised as purely discretionary, it is not only difficult to predict how it will be used, it is also impossible to criticise. Some cases in which public policy has been applied are controversial, but critics have struggled to articulate principled grounds on which to object to the decision. The principles developed in this article give greater substance to claims that public policy has been misapplied in particular cases. In these cases, the use of public policy is not merely wrong as a matter of private international law, but arguably (for reasons considered above ${ }^{143}$ ) a breach of constitutional norms, in that the misapplication of public policy fails to give proper effect to the primary policy of applying foreign law or recognising and enforcing foreign judgments.

\footnotetext{
${ }^{139}$ At p.164, per Lord Simon.

${ }^{140}$ At p.157, per Lord Hailsham.

${ }^{141}$ At p.166, per Lord Simon.

142 See section 3.1 above.

${ }^{143}$ See section 2.2 above.
} 
In the case of In re Macartney (1921) ${ }^{144}$, a Maltese court granted a judgment in which an estate was ordered to pay maintenance to an illegitimate child of the deceased, extending into adulthood. An English court controversially refused to recognise or enforce the judgment on the grounds that it (in particular, the extension of the award into adulthood) was contrary to public policy. Examined through the principles developed in this article, the dissatisfaction which is generally expressed with this decision may be more clearly explained. The case was one of reasonably low proximity to the forum state, involving the enforcement of an order involving a foreign estate against English assets. While the court cited Rousillon v Rousillon (1880) $)^{145}$ in support of the proposition that "this Court will not enforce a contract against the public policy of this country, wherever it may be made"146, that was a case (as examined above ${ }^{147}$ ) with a far greater proximity to England. Further, the norm which was at stake was only relative - the court acknowledged that the extension of a maintenance award into adulthood was not "so directly contrary to general morality as on that ground alone to be refused recognition in this country"148. The lack of proximity and the relativity of the norm together suggest that public policy ought not to have been applied in the circumstances of the case - they provide a principled ground for criticising the judgment.

A more recent dispute raises similar grounds for criticism - this time involving the enforcement in the United States of an English judgment. In the case of Telnikoff $v$ Matusevitch (1997) ${ }^{149}$, Telnikoff sued Matesevitch in the English courts for libel in respect of a publication in an English newspaper, and after lengthy litigation (including before the House of Lords ${ }^{150}$ ) was ultimately successful in obtaining an award for damages of $£ 240,000$. Before enforcement of the award could take place, Matusevitch moved to the United States, and Telnikoff thus attempted enforcement of the judgment there. Although codified in statute ${ }^{151}$, the principles applicable to the recognition and enforcement of the foreign judgment were broadly equivalent to those in England - including the possibility for the refusal of enforcement on the grounds of public policy. After the claim for enforcement was denied at first instance, the dispute came before the Court of Appeal of Maryland. The question was characterised as "whether Telnikoff's English libel judgment is based upon principles which are so contrary to Maryland's public policy concerning freedom of the press and defamation actions that recognition of the judgment should be denied"152. After reviewing the facts of the case in detail, and the diverging histories of libel law and freedom of the press protection in England and the United States (particularly drawing on United States First Amendment constitutional jurisprudence), the court emphasised that the

\footnotetext{
${ }^{144}$ In Re Macartney [1921] 1 Ch 522.

${ }^{145}$ Rousillon v Rousillon (1880) 14 Ch D 351.

${ }^{146}$ At p.369.

${ }^{147}$ See section 4.4 above.

${ }^{148}$ In Re Macartney [1921] 1 Ch 522 at 527.

${ }^{149}$ Telnikoff v Matusevitch, 702 A2d 230 (Md 1997). See generally Berman, PS, "Choice of Law and Jurisdiction on the Internet - Towards a Cosmopolitan Vision of Conflict of Laws: Redefining Governmental Interests in a Global Era" (2005) 153 University of Pennsylvania Law Review 1819 at p.1871; Youm, KH, "The Interaction Between American and Foreign Libel Law" (2000) 49 International and Comparative Law Quarterly 131.

${ }^{150}$ Telnikoff v Matusevitch [1992] 2 AC 343

${ }^{151}$ Maryland Code, Foreign Money-Judgments Recognition (s.10-701ff).

${ }^{152}$ Telnikoff v Matusevitch, 702 A2d 230 (Md 1997) at 239.
} 
judgment would not have been awarded if Maryland law had been applicable to the dispute, and concluded that:

"The principles governing defamation actions under English law, which were applied to Telnikoff's libel suit, are so contrary to Maryland defamation law, and to the policy of freedom of the press underlying Maryland law, that Telnikoff's judgment should be denied recognition under principles of comity. In the language of the Uniform Foreign-Money Judgments Recognition Act, $\S 10-704(b)(2)$ of the Courts and Judicial Proceedings Article, Telnikoff's English "cause of action on which the judgment is based is repugnant to the public policy of the State...",153

What is striking and controversial about this decision is that First Amendment standards were applied to refuse enforcement of a judgment almost entirely unconnected with the United States ${ }^{154}$. To put this another way, the dispute lacked proximity with the courts of Maryland, and thus the parochial application of public policy here looks like an attempt to give extraterritorial effect to United States norms ${ }^{155}$. In reaching its decision, the court relied extensively on the case of Bachchan v India Abroad Publications (1992) $)^{156}$ - although this was notably a case in which part of the publication took place in New York, and a failure to apply United States constitutional norms might thus potentially affect freedom of the press in the United States. In Telnikoff, by contrast, to cite the sole dissenting judge, "there is no United States or Maryland interest implicated by this judgment"157.

According to the analysis in this article, public policy might, despite the absence of proximity, nevertheless be applicable if the norm at stake was shared or absolute. The differences between United States and English law in this field and the unique character of First Amendment jurisprudence in the United States do not suggest that either of these grounds could justify the decision of the court. As the dissent argued, "this libel judgment obtained by one British resident against another British resident was not a 'serious injustice'; it does not violate fundamental notions of what is decent and just; and it does not undermine public confidence in the administration of law"158. The fact that Matusevitch, an England resident at the time, was subject to English libel law in respect of a suit by another English resident concerning a publication in an English newspaper cannot of itself be fundamentally objectionable to Maryland public policy - and his subsequent move to Maryland should not change this.

The constitutional perspective examined earlier in this article noted that public policy ought to be balanced against other policies, such as those embodied in choice of law

\footnotetext{
${ }^{153}$ Telnikoff $v$ Matusevitch, 702 A2d 230 (Md 1997) at 249.

${ }^{154}$ Matusevitch was born in New York, but after moving to Russia at aged four lived in various European countries, finally living in England at the time of the defamation, before moving to the United States.

${ }^{155}$ For a critical view from a constitutional perspective see Rosen, MD, "Exporting the Constitution" (2004) 53 Emory Law Journal 171.

${ }^{156}$ Bachchan v India Abroad Publications, 585 NYS 2d 661 (1992). See Devgun, D, "United States Enforcement of English Defamation Judgments: Exporting the First Amendment?" (1994) 23 AngloAmerican Law Review 195; Maltby, J, "Juggling Comity and Self-Government: The Enforcement of Foreign Libel Judgments in US Courts” (1994) 94 Columbia Law Review 1978.

157 Telnikoff v Matusevitch, 702 A2d 230 (Md 1997) at 258, per Chasanow J.

${ }^{158}$ At p.256, per Chasanow J.
} 
or judgment recognition rules, particularly (but not exclusively) where they were policies adopted by parliament in the form of a statute ${ }^{159}$. Consistently with this approach, the dissenting judge in this case noted that:

"Our interest in international good will, comity, and res judicata fostered by recognition of foreign judgments must be weighed against our minimal interest in giving the benefits of our local libel public policy to residents of another country who defame foreign public figures in foreign publications and who have no reasonable expectation that they will be protected by the Maryland Constitution". ${ }^{160}$

The case is rightly controversial because it appears to undermine the policy behind the rules on the recognition and enforcement of foreign judgments - public policy was applied in a case without proximity to the forum state to give effect to a clearly relative norm, violating the basic principle of tolerance of difference which underpins private international law.

\section{A residual discretion?}

The purpose of this article has been to articulate rules, largely consistent with the existing practice of the courts, which can be used to guide the application of public policy. To this extent, it rejects the view that the use of public policy by the courts is inherently discretionary. However, this is perhaps subject to one important qualification. The courts may retain a discretion to refuse the application of public policy, even if the dispute falls within the range of cases in which the application of public policy is justifiable. According to this approach, where the application of public policy might itself cause an injustice, the courts may refuse to apply $\mathrm{it}^{161}$.

The perceived need for such a discretion is easily illustrated. Consider, for example, a couple who marry in a foreign state, contrary to a law which forbids their marriage on racially discriminatory grounds, and then subsequently move to England ${ }^{162}$. If one party was later to seek to assert rights to maintenance or inheritance in an English court, it is highly likely that the court would apply English public policy to invalidate the discriminatory foreign law, upholding the marriage. If, however, the couple amicably separated and one party remarried relying on the foreign law invalidating the initial marriage, it is at least arguable that the court should not apply public policy to deny effect to the discriminatory foreign law, as it could cause an injustice between the parties.

Whether such a residual discretion should operate is a difficult question. It is related to the uncertainty, noted above ${ }^{163}$, as to whether public policy operates against a

\footnotetext{
${ }^{159}$ See section 2.2 above.

${ }^{160}$ At p.257, per Chasanow J.

${ }^{161}$ But see Mann, FA, "The Consequences of an International Wrong in International and National Law" (1976-7) 48 British Yearbook of International Law 1 at p.45 (arguing that such a discretion should not operate in respect of truly international public policy).

${ }^{162}$ See, eg, Carter, PB, "The Role of Public Policy in English Private International Law" (1993) 42 International and Comparative Law Quarterly 1 at p.4.

${ }^{163}$ See section 3.1 above.
} 
foreign law per se, or only the outcome of the application of the foreign law in the specific circumstances. Any optional provision for excluding public policy on the grounds of justice would clearly risk reintroducing the criticised discretionary character of the public policy exception. Even if it exists, however, the existence of such a residual discretion would not undermine the need for the development of principles limiting the application of public policy - even if they are subject to additional limitations, the principles examined in this article would still establish when public policy may or may not be invoked by the courts.

\section{Conclusions}

The doctrine of public policy serves a fundamentally important function in demarcating the limits of the principles of tolerance underpinning rules on the application of foreign law and the recognition and enforcement of foreign judgments. However, it has been, not unfairly, much criticised for its vagueness and uncertainty of application and for its discretionary character. There are clear justifications for limits on the use of public policy in private international law, including constitutional concerns. Such limits are essential to avoid public policy becoming "an intolerable affectation of superior virtue" 164 or even an instance of "cultural imperialism"165, undermining the system of mutual respect, of tolerance, which is at the heart of private international law. This article argues that these justifications can be examined to assist in formulating guidelines for when it is appropriate for public policy to be invoked to refuse an application of foreign law or the recognition and enforcement of a foreign judgment.

The principles identified in this article suggest that the application of public policy should reflect three concerns. First, as a subsidiary form of choice of law rule, it should reflect the degree of proximity of the dispute with the forum state. Second, the willingness to apply public policy should reflect the relativity of the norm which is breached - the extent to which it is shared with other interested states or absolute (ought to be shared). Where shared or absolute norms are involved, such as when public policy is sourced from European or international law, it is transformed from a negative exclusionary doctrine to a positive mechanism for enforcing those norms. In this context, however, an additional concern may arise - public policy may be limited as a consequence of the need for deference to other means of enforcement (such as specialised regional courts). Third, public policy should be more easily invoked depending on the seriousness of the breach.

Representing these principles as dimensions on a 'map' allows a diagrammatic analysis of the limits of tolerance in private international law, which provides an important framework for the examination of the practice of the English courts. The proximity of the dispute and the shared or absolute character of a norm are each justifications for the application of that norm as part of public policy. If both are present in a high degree, then the application of public policy is clearly justified (Category A). If neither is present in a high degree, then it is clearly not justified

\footnotetext{
${ }^{164}$ Beach, JK, "Interstate Enforcement of Vested Rights" (1918) 27 Yale Law Journal 656 at p.662 (writing in the context of disputes within the United States).

${ }^{165}$ Murphy, J, "Rationality and Cultural Pluralism in the Non-Recognition of Foreign Marriages" (2000) 49 International and Comparative Law Quarterly 643.
} 
(Category D). If only one is present, then it must be present in a high degree to justify public policy (Category B or C). If, however, both are present in an intermediate degree, their combination may provide a compelling basis on which to invoke public policy (Category E).

The analysis in this article suggests that, although the English courts have not articulated guidelines restraining the use of public policy, the case law is broadly consistent with principled limits. These principles do not only assist in explaining the general practice of the courts, but also provide a basis for analysing why in some cases the application of public policy has been viewed as erroneous. It is, of course, not suggested that courts have in the past, or ever will in future, use public policy in a way which is entirely predictable or rule-driven. Nevertheless, it is hoped that the framework articulated in this article might help provide guidance for future cases, making the application of public policy in private international law more certain, principled and justifiable.

\section{June 2008}

